\title{
Article \\ Effects of Environmental Changes on Gerromorpha (Heteroptera: Hemiptera) Communities from Amazonian Streams
}

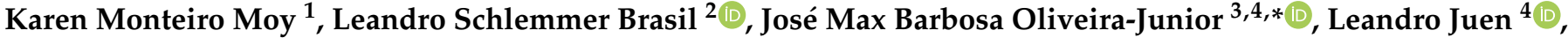 \\ Thiago Bernardi Vieira ${ }^{1}$ (D) and Karina Dias-Silva ${ }^{1}$
}

\section{check for}

updates

Citation: Moy, K.M.; Brasil, L.S.;

Oliveira-Junior, J.M.B.; Juen, L.;

Vieira, T.B.; Dias-Silva, K. Effects of

Environmental Changes on

Gerromorpha (Heteroptera:

Hemiptera) Communities from

Amazonian Streams. Hydrobiology

2022, 1, 111-121. https://doi.org/

10.3390/hydrobiology1010008

Academic Editors: Lucian Pârvulescu and Octavian Pacioglu

Received: 9 January 2022

Accepted: 8 February 2022

Published: 15 February 2022

Publisher's Note: MDPI stays neutral with regard to jurisdictional claims in published maps and institutional affiliations.

Copyright: (C) 2022 by the authors. Licensee MDPI, Basel, Switzerland. This article is an open access article distributed under the terms and conditions of the Creative Commons Attribution (CC BY) license (https:// creativecommons.org/licenses/by/ $4.0 /)$.
1 Programa de Pós-Graduação em Biodiversidade e Conservação (PPGBC), Universidade Federal do Pará (UFPA), Rua Coronel José Porfírio, N. 2515, Bairro São Sebastião, Altamira 68372-040, Brazil; karenmonteiro.km@gmail.com (K.M.M.); vieiratb@ufpa.br (T.B.V.); diassilva@ufpa.br (K.D.-S.)

2 Instituto de Ciências Biológicas e da Saúde (ICBS), Universidade Federal de Mato Grosso (UFMT), Avenida Universitária, N. 3.500, Bairro Parque Universitário, Pontal do Araguaia 78690-000, Brazil; leandrobrasilecologia@gmail.com

3 Instituto de Ciências e Tecnologia das Águas (ICTA), Universidade Federal do Oeste do Pará (UFOPA), Rua Vera Paz, s/n (Unidade Tapajós) Bairro Salé, Santarém 68040-255, Brazil

4 Programa de Pós-Graduação em Ecologia (PPGECO), Laboratório de Ecologia e Conservação (LABECO), Universidade Federal do Pará (UFPA), Rua Augusto Correia, N.1, Bairro Guamá, Belém 66075-110, Brazil; leandrojuen@gmail.com

* Correspondence: jose.mbo@ufopa.edu.br

\begin{abstract}
The presence of environmental conditions that are suitable for the development of agricultural and cattle-raising activities has favored the expansion of land use in the Brazilian Amazon. This expansion changes the environmental conditions of aquatic ecosystems by altering the structure of the streambeds and the physicochemical conditions of the water. Therefore, this manuscript aimed to assess the effect of changes in environmental conditions along a gradient of different land uses on the richness and species composition of Gerromorpha (Heteroptera: Hemiptera) communities in streams from the Brazilian Amazon. We sampled Gerromorpha communities and environmental variables (physical structure of the habitat and physicochemical characteristics of the water) in 45 streams in the municipality of Paragominas in the state of Pará, Brazil. We then performed variation partitioning analyses to assess the relative contribution of habitat structure and water physicochemical variables on the richness and species composition. The Habitat Integrity Index (HII), which measures the habitat physical structure, was the best predictor of species richness. The HII and physicochemical variables were jointly the best predictors of species composition. Our results show that Gerromorpha communities respond to gradients of environmental anthropization in the Amazon region, which reinforces the importance of habitat integrity and water quality for the maintenance of Gerromorpha communities.
\end{abstract}

Keywords: aquatic insects; water electrical conductivity; environmental predictors; land use; environmental integrity; Amazon

\section{Introduction}

Anthropic activities such as agriculture and cattle raising can change the natural landscape, altering its environmental conditions and resources and resulting in generally negative impacts on the structure of aquatic communities [1]. These effects are even stronger for sensitive and complex systems such as lower-order streams [2] because the changes that take place within the drainage basin also modify the physical structure of the stream, its environmental integrity, and its water quality [3,4]. The Amazon basin is one of the largest river basins in the world and consists of a complex network of water bodies [5]. This hydric system then consists of a hierarchical set of sub-basins that are drained by streams 
that supply the larger Amazon basin [6]. This drainage network naturally passes through large portions of dry and flooded forests connecting aquatic and terrestrial environments, providing allochthonous energy to the biota [7].

The main consequences of anthropic changes in the landscape surrounding aquatic ecosystems are the reduction or total loss of the riparian forests, changes in the stream banks for the reuse of the streambed or by erosion, soil exposure, and siltation, homogenization of the streambed by the entrance of sediments into the channel, and a decrease in the diversity of microhabitats [8-10]. These anthropic changes can go further and cause a decrease in the abundance of the most sensitive species or even lead them to local extinction. However, they may also facilitate colonization and promote an increase in the abundance of hardy and tolerant species, thus changing the structure of aquatic communities [11-13].

Changes in the aquatic community structure, such as changes in richness and species composition patterns may be a consequence of changes in the environmental conditions (e.g., air and water temperature, flow speed, depth, channel width, and type of substrate on the channel and the stream banks) and resource availability (e.g., leaves and wood packs that are used for shelter and food, nesting sites, and foraging substrates) [14]. The structure of aquatic communities in Amazonian streams is affected both by environmental variables related to land-use change (resources and environmental conditions) at the landscape scale, and variables at the local scale, such as changes in habitat integrity, in the structure of the channel edges, the type of substrate on the streambed, the presence of leaf and wood packs, and water quality $[15,16]$.

The Habitat Integrity Index (HII) [17] is often used to quantify the environmental change in Amazonian streams. It is an important tool because it captures the impacts of land-use change both at the landscape scale, such as the state of preservation of riparian forests, and at the local scale, such as environmental changes inside the streams [18], which can even indirectly reflect aspects of the water quality [19]. Therefore, the HII is appropriate to predict the distribution of different taxonomic groups such as aquatic insects of the Ephemeroptera, Plecoptera, Trichoptera, Odonata, and Heteroptera orders [18]. The $\mathrm{HII}$ has also been shown to be more suitable than other landscape metrics to predict the distribution of Heteroptera insects in anthropized gradients [20].

The Heteroptera (Hemiptera) have been frequently used in studies that evaluate anthropized aquatic environments in the Amazon region [15,16,21-23]. The Gerromorpha, an infraorder within the Heteroptera order, is comprised of semiaquatic individuals that move on the water surface preying upon other aquatic insects that emerge from the aquatic environment, and those that fall from the marginal vegetation. They are considered sensitive to both natural and anthropic environmental change [24]. Changes in the habitat structure can alter the physicochemical variables of the water, which in turn have negative effects on the taxonomic diversity of Gerromorpha $[16,20,25]$ or even change the morphology of individuals such as wing dimorphism [26].

Previous studies claimed that the Heteroptera were resistant to environmental change [27]. However, more recent studies have shown negative effects of environmental change on Heteroptera communities [15,16,21,24-26,28]. Ephemeroptera, Plecoptera, Trichoptera, and Odonata were considered to be more sensitive to losses of habitat integrity in tropical streams than Heteroptera [18]. However, a recent literature synthesis showed that the Heteroptera are as efficient as bioindicators as these others. Considering these organisms, recent studies have shown that anthropic changes can alter species interactions [22] and diversity metrics such as species richness and composition [16,24,25].

Within this context, the present study aims to assess the effect of land use changes at local and landscape scales on Gerromorpha species richness and composition in streams from a region subject to multiple land-uses in the Brazilian Amazon. We hypothesize that the HII will be a better predictor of the Heteroptera communities than landscape or water quality variables [20] since this index can reflect both environmental impacts in habitat structure inside the streams and its surroundings $[19,29]$. 


\section{Materials and Methods}

\subsection{Study Area}

We sampled 45 streams varying from first to third order (according to Strahler [30]) located in the municipality of Paragominas, the northeastern state of Pará, Brazil (Figure 1). The region's climate is mostly rainy and tropical (Köppen's "Aw") with monthly precipitation lower than $60 \mathrm{~mm}$, an average annual temperature of $27.2{ }^{\circ} \mathrm{C}$, air humidity of $81 \%$, and average annual precipitation of $2000 \mathrm{~mm}$ [31-33]. The region's vegetation type consists of dense rain forests, tropical open forests mixed with lianas and palm trees, and dense alluvial forests [33].

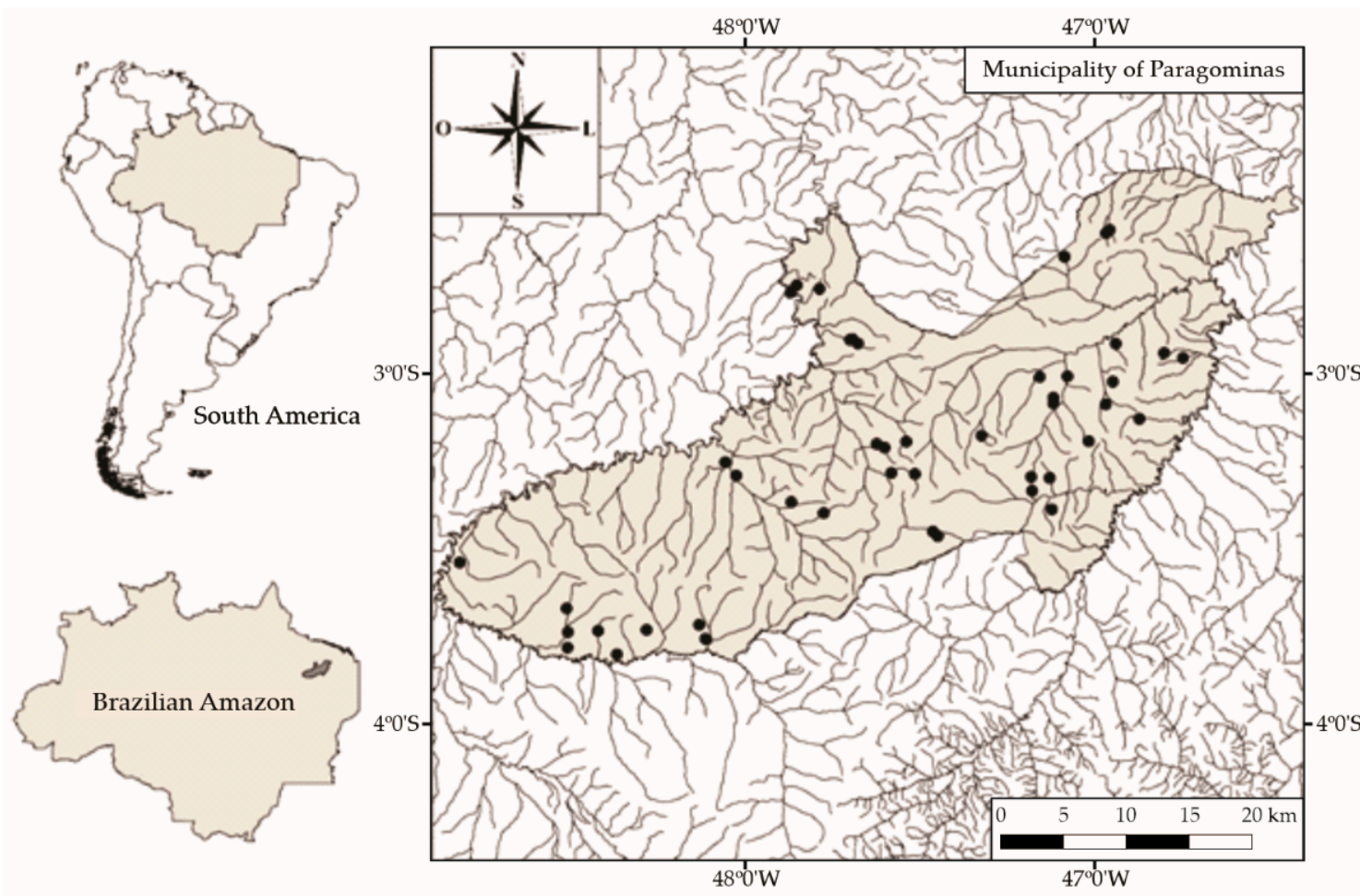

Figure 1. Spatial distribution of the 45 sampled streams (black dots) in 2011 in the municipality of Paragominas, Pará, Brasil.

The streams were distributed along a gradient of anthropic impact. We selected streams aiming to encompass drainage microbasins with different amounts of native forest remnants and anthropized areas [33]. This region is considered a mosaic of land uses due to its historical land-use patterns. It drains a landscape under the direct and indirect influence of the deforestation process and the construction of federal roads. The region also exhibits mechanized agricultural activities, silviculture, urban areas that are important for the cattle business, and activities that are carried out both by small farmer-colonies and settlements, and large agribusiness farms (see Gardner et al. [33] and Oliveira-Junior et al. [34] for more details).

\subsection{Data Collection}

\subsubsection{Biological Sampling}

The streams were sampled during the dry season between June and August of 2011 due to the lower stream depth and width, which increases the sampling efficiency. It also decreases possible seasonality effects [35-37]. Therefore, the collection of field data in studies of Heteroptera ecology in Brazil are mostly carried out during the dry season [15,16,21].

We delimited a transect with a length of $150 \mathrm{~m}$, which was divided into ten smaller sections of $15 \mathrm{~m}[38,39]$. The Gerromorpha were sampled on the water surface. The 
sampling effort was three minutes of active capture in each section with a handnet $(18 \mathrm{~cm}$ of diameter and $1 \mathrm{~mm}$ mesh) following the protocol adapted from Cabette et al. [40]. The specimens were identified to species level in the laboratory using a dichotomous key [41-49]. They were then deposited in the Zoological Collection of the Federal University of Pará (UFPA), in Belém, Pará, Brazil.

\subsubsection{Environmental Characteristics}

We measured the following four water physicochemical variables in each stream using a Horiba ${ }^{\circledR}$ multiparameter probe: dissolved oxygen $\mathrm{mg} / \mathrm{L}$ (DO), electrical conductivity $\mu \mathrm{S}$ (Cond), temperature ${ }^{\circ} \mathrm{C}$ (Temp), and $\mathrm{pH}$.

\subsubsection{Habitat Structure}

We used the physical habitat structure evaluation protocol $[38,39]$ to characterize the habitat structure. We then selected 44 variables within this protocol that were pointed out as important for Heteroptera by the literature [15,16,21,24,26]. A total of 29 of those variables measure local habitat characteristics, and 15 measure landscape metrics (Table S1). We also used the Habitat Integrity Index (HII) [17], which is an efficient predictor of tropical Heteroptera communities in anthropized environmental gradients [18].

\subsection{Data Analysis}

We considered each stream as a sample unit. The environmental variables were our predictor variables, and the richness and species composition were our response variables. The environmental descriptors were divided into three subsets: water physicochemical variables (1), local habitat variables (2), and landscape variables (3). We used a forward stepwise model selection procedure for each variable subset using the step function from the stats base package (version 3.6.2) to reduce the number of variables in the model, thus reducing model inflation and increasing efficiency. As we had a matrix as our response variable for the analysis of species composition, we performed a forward model selection for each variable subset separately using the function forward.sel from the adespatial package (version 0.3-14) [50]. We also built spatial filters (Principal Coordinates of Neighbour Matrices) to assess a possible spatial autocorrelation effect on both the species richness and composition.

We performed a partial redundancy analysis (partial RDA) to assess the effect of the in-stream environmental conditions and land-use changes at the landscape scale using the varpart function from package vegan (version 2.5-7) [51]. We Hellinger-transformed the species matrix to reduce the dominance effect of the most common species. We also standardized the environmental variables so that they were on comparable measurement scales. The statistical significance of each component was tested through the RDA function from package vegan [51]. We could not perform the variation partitioning for species richness because only one predictor was selected. In this case, we performed a simple linear regression [52]. All analyses were performed in the $R$ environment (version 3.6.2) [53] according to the assumptions when they exist.

\section{Results}

\subsection{Community Description}

We sampled 2212 individuals distributed in three families, 11 genera, and 36 species. The Vellidae family $(n=1551)$ was the most abundant and diverse. Rhagovelia was the most representative genus $(n=1375)$ and encompassed 12 species. The most representative species were: Rhagovelia evidis $(n=683)$, Cylindrostethus palmaris $(n=535)$, Rhagovelia elegans $(n=317)$, Rhagovelia hambletoni $(n=104)$, Rhagovelia sp. 6 (angustipes complex) $(n=103)$, and Stridulivelia tersa $(n=102)$ (Table 1$)$. 
Table 1. Description of the Gerromorpha (Heteroptera: Hemiptera) community sampled in streams from the municipality of Paragominas, Pará, Brazil.

\begin{tabular}{|c|c|c|}
\hline Family & Species & N. Individuals \\
\hline \multirow{8}{*}{ Gerridae } & Brachymetra lata Shaw, 1933 & 56 \\
\hline & Cylindrostethus palmaris Drake and Harris, 1934 & 535 \\
\hline & Limnogonus aduncus Drake and Harris, 1933 & 10 \\
\hline & Limnogonus cf. ignotus Drake and Harris, 1934 & 2 \\
\hline & Limnogonus recurvus Drake and Harris, 1930 & 12 \\
\hline & Neogerris lotus (White, 1879) & 28 \\
\hline & Tachygerris adamnsoni (Drake, 1942) & 3 \\
\hline & Tachygerris celosis (Drake and Harris, 1931) & 6 \\
\hline \multirow{2}{*}{ Hydrometridae } & Hydrometra comata (Torre-Bueno, 1926) & 4 \\
\hline & Hydrometra guianana (Hungerford and Evans, 1934) & 2 \\
\hline \multirow{26}{*}{ Veliidae } & Euvelia concava Polhemus and Polhemus, 1984 & 18 \\
\hline & Microvelia longipes Uhler, 1893 & 1 \\
\hline & Microvelia pulchella Westwood, 1834 & 2 \\
\hline & Paravelia bullialata Polhemus and Polhemus, 1984 & 9 \\
\hline & Rhagovelia aff. scitula (Bacon, 1956) & 1 \\
\hline & Rhagovelia elegans Uhler, 1894 & 317 \\
\hline & Rhagovelia evidis Bacon, 1948 & 683 \\
\hline & Rhagovelia hambletoni Drake and Harris, 1933 & 104 \\
\hline & Rhagovelia jubata Bacon, 1948 & 58 \\
\hline & Rhagovelia robusta Gould, 1931 & 1 \\
\hline & Rhagovelia sp. 1 & 15 \\
\hline & Rhagovelia sp. 2 & 24 \\
\hline & Rhagovelia sp. 3 & 1 \\
\hline & Rhagovelia sp. 4 & 13 \\
\hline & Rhagovelia sp. 5 & 55 \\
\hline & Rhagovelia sp. 6 (angustipes complex) & 103 \\
\hline & Stridulivelia alia (Drake, 1957) & 1 \\
\hline & Stridulivelia astralis (Drake and Harris, 1938) & 12 \\
\hline & Stridulivelia cf. ayacucho Polhemus and Spangler, 1995 & 3 \\
\hline & Stridulivelia quadrispinosa (Hungerford, 1929) & 1 \\
\hline & Stridulivelia raspa (Hungerford, 1929) & 5 \\
\hline & Stridulivelia sp. 1 & 2 \\
\hline & Stridulivelia stridulata (Hungerford, 1929) & 2 \\
\hline & Stridulivelia strigosa (Hungerford, 1929) & 16 \\
\hline & Stridulivelia tersa (Drake and Harris, 1941) & 102 \\
\hline & Stridulivelia transversa (Hungerford, 1929) & 5 \\
\hline Total & & 2212 \\
\hline
\end{tabular}

\subsection{Effect of Environmental Variables on Community Structure}

None of the spatial filters were significantly related to species richness or species composition, indicating that there was no spatial autocorrelation bias. The water electrical conductivity remained the best predictor of species composition among the water variables $\left(\mathrm{R}^{2}=0.093 ; \mathrm{F}=4.457 ; p=0.002\right)$. The HII was the best habitat predictor of species composition $\left(R^{2}=0.075 ; F=3.508 ; p=0.007\right)$ and species richness $\left(R^{2}=0.135 ; F=6.765 ; p=0.012\right)$ (Figure 2). 


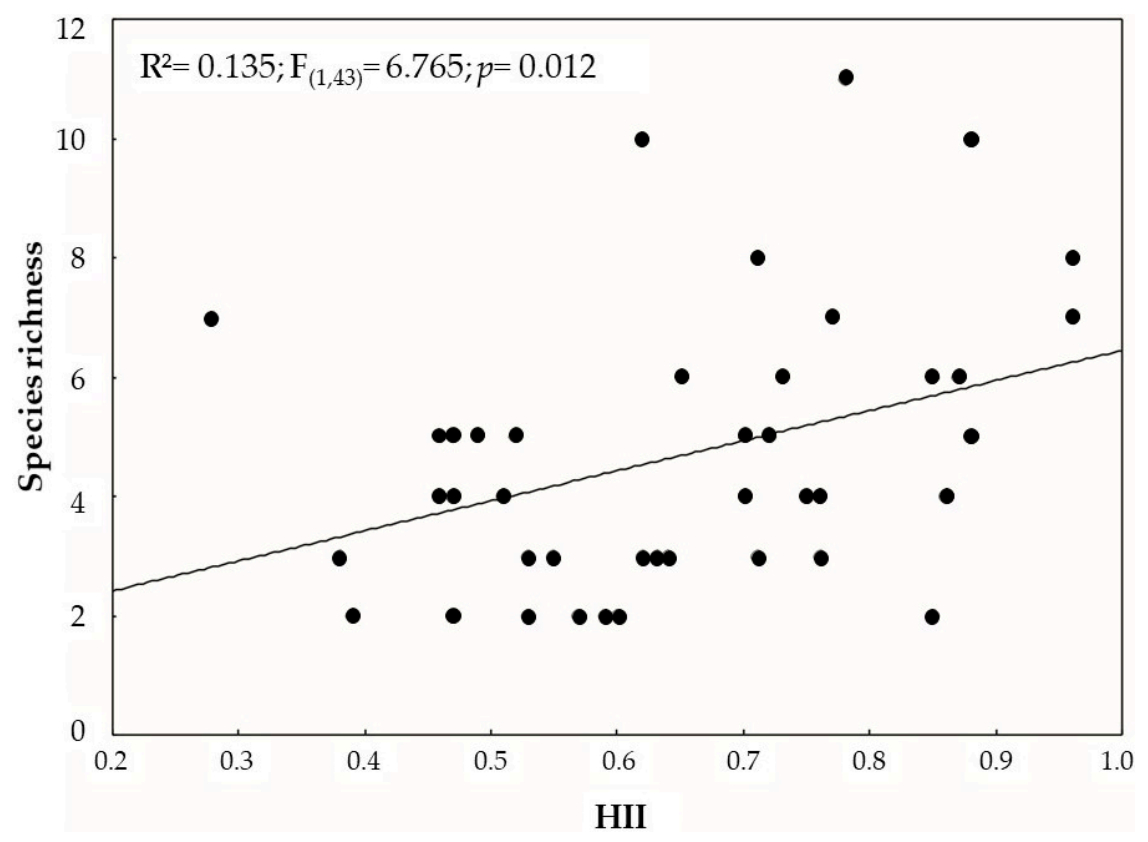

Figure 2. Linear regression between Gerromorpha (Heteroptera: Hemiptera) species richness and Habitat Integrity Index-HII in streams sampled in the municipality of Paragominas, Pará, Brazil.

The selected predictor variables explained $12 \%$ of the variation in species composition. Of those, $4 \%$ was explained exclusively by the local habitat, which was represented by the $\mathrm{HII}(\mathrm{F}=2.859 ; p=0.026), 6 \%$ was exclusively explained by water electrical conductivity $(\mathrm{F}=3.774 ; p=0.008)$, and $2 \%$ was explained by the interaction between $\mathrm{HII}$ and water electrical conductivity (Figure 3).
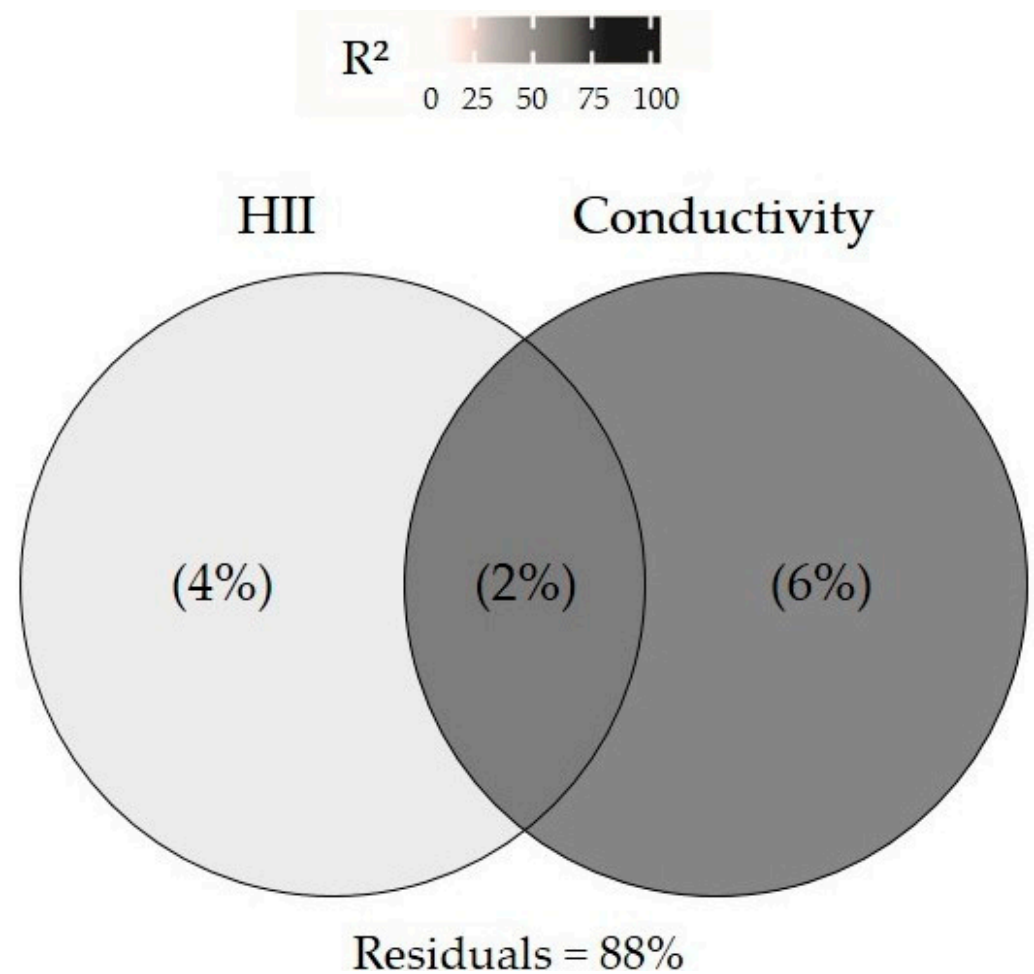

Figure 3. Variation partitioning of the Gerromorpha (Heteroptera: Hemiptera) species composition between the Habitat integrity Index and water electrical conductivity in streams sampled in the municipality of Paragominas, Pará, Brazil. 


\section{Discussion}

The HII was a good local habitat predictor both of species richness and species composition. However, after considering the relative importance of the local habitat variables, landscape variables, and physicochemical variables, the HII was the single best predictor of species richness, which confirmed our hypothesis. Despite the increase in studies showing the relationship of aquatic insects with environmental variables, many variables that are important for structuring communities remain unmeasured or even difficult to understand [54,55]. These include variables that may be related to hydrology, climate, biome type, substrate, biotic interactions, or historical factors [56-59]. The water electrical conductivity was the best predictor of species composition, rejecting our hypothesis for these components. The changes in the HII and electrical conductivity come from anthropic impacts, and many studies (for example, $[15,16,21,24,26]$ ) have shown that Gerromorpha communities are modified by anthropic activities.

The Habitat Integrity Index (HII) indirectly measures variations in habitat structure related to the stream's degree of conservation [18-20]. The relationship between the HII and Gerromorpha communities is well known in communities from the Cerrado $[15,24,25]$, the Amazon Forest $[16,21]$, and other biomes such as the Atlantic Forest, as shown by Brasil et al. [18]. The Gerromorpha species richness increased with the increase of environmental integrity, indicating that the changes caused by land use nearby the stream channel are essential for the maintenance of these communities, which rely on suitable habitats for oviposition and foraging [44,60]. Other studies of Odonata [61,62] and EPT (Ephemeroptera, Plecoptera and Trichopteta) communities [63] showed a relationship between the communities and the HII, reinforcing the direct relationship with environmental quality and aquatic insect communities of several orders. The relationship between the Gerromorpha species composition and the HII was also shown by Cunha and Juen [21] when they observed changes in species composition through the HII, where more generalist species were found only in places with low HII, and more specialist ones were found in places with higher HII.

Electrical conductivity was the most important variable among the water physicochemical variables to explain the Gerromorpha communities. This variable represents the sum of dissolved ions, which directly relates to the nitrate concentration, suggesting that agricultural activities might be contributing to the variation in this variable in the sample streams [64]. The water conductivity is positively associated with deforestation [65] and environmental integrity [29] in tropical environments. There are also indications that changes in electrical conductivity may result in changes in Heteroptera communities [66,67].

Conductivity has already been indicated as a predictor of Gerromorpha species distribution in Amazonian streams due to a change in species composition across a gradient of conductivity [21,28]. Cunha and Juen [21] found an association between more generalist species such as Rhagovelia brunae with high values of conductivity, whereas more sensitive species such as $R$. jubata and R. evidis exhibited lower abundances in areas with lower conductivity. Similar to what we found in this study, Godoy et al. [68] also found a greater explanation of water conductivity for the abundance of Heteroptera in Cerrado streams. There are indications that conductivity is one of the main components of the water in gradients altered by multiple land uses [69], which may also change the water's surface tension [58]. Such change would certainly affect the movement and dispersal of the Gerromorpha communities due to their skater habit [70]. However, there is no evidence directly showing the possible effect of water conductivity on their skating ability or changes in water superficial tension.

\section{Conclusions}

In this study, we conclude that the habitat structure, especially environmental integrity (represented by the HII), is important in predicting Gerromorpha species richness. However, we highlight that water characteristics, especially electrical conductivity, also have significant effects on the structuring of these communities. Therefore, we must better 
understand the processes or mechanisms that drive these relationships to have a better comprehension of the distribution of the Gerromorpha communities in areas that are impacted by changes in land use. We emphasize that the environmental integrity is still an important predictor of the Gerromorpha communities; however, the water conductivity is also an important environmental predictor and must be considered. We suggest that experimental studies must be carried out to evaluate if the relationship between the Heteroptera and water electrical conductivity is affected by changes in the water's superficial tension, which would directly affect the movement ability of skaters on the water surface.

Supplementary Materials: The following supporting information can be downloaded at: https:/ /www. mdpi.com/article/10.3390/hydrobiology1010008/s1, Table S1: Description of the sets of variables used in data analysis.

Author Contributions: Conceptualization, K.M.M. and K.D.-S.; methodology, K.M.M. and K.D.-S.; formal analysis, K.M.M., L.S.B., T.B.V. and K.D.-S.; investigation, K.M.M., L.S.B., J.M.B.O.-J., T.B.V., L.J. and K.D.-S.; resources, K.M.M., L.J. and K.D.-S.; data curation, K.M.M. and K.D.-S.; writing-original draft preparation, K.M.M., L.S.B., J.M.B.O.-J., T.B.V., L.J. and K.D.-S.; writing-review and editing, K.M.M., L.S.B., J.M.B.O.-J., T.B.V., L.J. and K.D.-S.; visualization, K.M.M., L.S.B., J.M.B.O.-J., T.B.V., L.J. and K.D.-S.; supervision, K.D.-S.; project administration, L.S.B., J.M.B.O.-J., L.J. and K.D.-S.; funding acquisition, L.J. and K.D.-S. All authors have read and agreed to the published version of the manuscript.

Funding: This research was funded by National Council for Scientific \& Technological Development (CNPq), grant number 304710/2019-9.

Institutional Review Board Statement: Not applicable.

Informed Consent Statement: Not applicable.

Data Availability Statement: Not applicable.

Acknowledgments: The authors thank the Rede Amazônia Sustentável (RAS). K.M.M. thanks the Coordenação de Aperfeiçoamento de Pessoal de Nível Superior (CAPES) scholarship. L.J. thanks the National Council for Scientific \& Technological Development (CNPq) for the research productivity grants 304710/2019-9.

Conflicts of Interest: The authors declare no conflict of interest.

\section{References}

1. Grasni, P.; Kent, M.E.; Kenneth, G.C. Distinguishing between yield advances and yield plateaus in historical crop production trend. Nat. Commun. 2013, 4, 2918. [CrossRef]

2. Allan, J.D.; Castilho, M.M. Stream Ecology: Structure and Function of Running Waters; Kluwer Academic Publishers: Amsterdam, The Netherlands, 2007; p. 436.

3. Vannote, R.L.; Minshall, G.W.; Cummins, K.W.; Sedell, J.R.; Cushing, C.E. The river continuum concept. Can. J. Fish. Aquat. Sci. 1980, 37, 130-137. [CrossRef]

4. $\quad$ Dala-Corte, R.B.; Melo, A.S.; Siqueira, T.; Bini, L.M.; Martins, R.T.; Cunico, A.M.; Pes, A.M.; Magalhães, A.L.B.; Godoy, B.S.; Leal, C.G.; et al. Thresholds of freshwater biodiversity in response to riparian vegetation loss in the Neotropical region. J. Appl. Ecol. 2020, 57, 1391-1402. [CrossRef]

5. Latrubesse, E.M.; Arima, E.Y.; Dunne, T.; Park, E.; Baker, V.; Horta, F.M.; Wight, C.; Wittmann, F.; Zuanon, J.; Baker, P.A.; et al. Damming the rivers of the Amazon basin. Nature 2017, 546, 363-369. [CrossRef]

6. Franken, W.; Leopoldo, P.R. Hydrology of catchment areas of Central-Amazonian forest streams. In The Amazon; Springer: Dordrecht, The Netherlands, 1984; pp. 501-519.

7. Junk, W.J.; Bayley, P.B.; Sparks, R.E. The Food pulse concept in river-Floodplain system. Can. J. Fish. Aquat. Sci. 1989, 106, 110-127.

8. Davidson, E.A.; Neill, C.; Krusche, A.V.; Ballester, M.V.R.; Markewitz, D.; Figueiredo, R.O. Loss of nutrients from terrestrial ecosystems to streams and the atmosphere following land use change in Amazonia. In Ecosystems and Land Use Change; Defries, R., Asner, G., Houghton, H.R., Eds.; American Geophysical Union: Washington, DC, USA, 2004; Volume 153, pp. 147-158.

9. Teresa, F.B.; Casatti, L. Importância da vegetação ripária em região intensamente desmatada no sudeste do Brasil: Um estudo com peixes de riacho. Pan Am. J. Aquat. Sci. 2010, 5, 444-453.

10. Höbinger, T.S.; Schindler, B.; Seaman, S.; Wrbka, T.; Weissenhofer, A. Impact of oil palm plantations on the structure of the agroforestry mosaic of La Gamba, southern Costa Rica: Potential implications for biodiversity. Agrofor. Syst. 2012, 85, 367-381. [CrossRef] 
11. Allan, J.D. Landscapes and riverscapes: The influence of land use on stream ecosystems. Annu. Rev. Ecol. Evol. Syst. 2004, 35, 257-284. [CrossRef]

12. Newbold, T.; Hudson, L.N.; Hill, S.L.L.; Contu, S.; Lysenko, I.; Senior, R.A.; Börger, L.; Bennett, D.J.; Choimes, A.; Collen, B.; et al. Global effects of land use on local terrestrial biodiversity. Nature 2015, 520, 45-50. [CrossRef] [PubMed]

13. Juen, L.; Cunha, E.J.; Carvalho, F.G.; Ferreira, M.C.; Begot, T.O.; Andrade, A.L.; Montag, L.F.A. Effects of oil palm plantations on the habitat structure and biota of streams in Eastern Amazon. River Res. Appl. 2016, 32, 2081-2094. [CrossRef]

14. Hutchinson, G.E. Concluding remarks. Cold Spring Harbor. Symp. Quant. Biol. 1957, 22, 415-427. [CrossRef]

15. Vieira, T.B.; Dias-Silva, K.; Pacífico, E.S. Effects of riparian vegetation integrity on fish and heteroptera communities. Appl. Ecol. Environ. Res. 2015, 13, 53-65. [CrossRef]

16. Cunha, E.J.; Montag, L.F.A.; Juen, L. Oil palm crops effects on environmental integrity of Amazonian streams and Heteropteran (Hemiptera) species diversity. Ecol. Indic. 2015, 52, 422-429. [CrossRef]

17. Nessimian, J.L.; Venticinque, E.; Zuanon, J.; De Marco, P.; Gordo, M.; Fidelis, L.; Batista, J.D.; Juen, L. Land use, habitat integrity, and aquatic insect assemblages in Central Amazonian streams. Hydrobiologia 2008, 614, 117-131. [CrossRef]

18. Brasil, L.S.; Lima, E.L.; Spigolonic, Z.A.; Ribeiro-Brasil, D.R.G.; Juen, L. The habitat integrity index and aquatic insect communities in tropical streams: A meta-analysis. Ecol. Indic. 2020, 116, 106495. [CrossRef]

19. Veras, D.S.; Castro, E.R.; Lustosa, G.; Azevedo, C.A.S.; Juen, L. Evaluating the habitat integrity index as a potential surrogate for monitoring the water quality of streams in the cerrado-caatinga ecotone in northern Brazil. Environ. Monit. Assess. 2019, 191, 562-571. [CrossRef] [PubMed]

20. Dias-Silva, K.; Vieira, T.B.; de Matos, T.P.; Juen, L.; Simião-Ferreira, J.; Hughes, R.M.; De Marco, P., Jr. Measuring stream habitat conditions: Can remote sensing substitute for field data? Sci. Total Environ. 2021, 788, 147617. [CrossRef]

21. Cunha, E.J.; Juen, L. Impacts of oil palm plantations on changes in environmental heterogeneity and Heteroptera (Gerromorpha and Nepomorpha) diversity. J. Insect Conserv. 2017, 21, 119. [CrossRef]

22. Guterres, A.P.; Cunha, E.J.; Godoy, B.S.; Silva, R.R.; Juen, L. Co-occurrence patterns and morphological similarity of semiaquatic insects (Hemiptera: Gerromorpha) in streams of Eastern Amazonia. Ecol. Entomol. 2020, 45, 155-166. [CrossRef]

23. Martins, R.T.; Brito, J.; Dias-Silva, K.; Leal, C.G.; Leitão, R.P.; Oliveira, V.C.; Oliveira-Junior, J.M.B.; Ferraz, S.B.; De Paula, F.; Roque, F.O.; et al. Low forest-loss thresholds threaten Amazonian fish and macroinvertebrate assemblage integrity. Ecol. Indic. 2021, 127, 107773. [CrossRef]

24. Dias-Silva, K.; Cabette, H.S.R.; Juen, L.; De Marco, P. The influence of habitat integrity and physical-chemical water variables on the structure of aquatic and semi-aquatic Heteroptera. Zoologia 2010, 27, 918-930. [CrossRef]

25. Dias-Silva, K.; Brasil, L.S.; Juen, L.; Cabette, H.S.R.; Costa, C.C.; Freitas, P.V.; De Marco, P., Jr. Influence of local variables and landscape metrics on Gerromorpha (Insecta: Heteroptera) assemblages in savanna streams, Brasil. Neotrop. Entomol. 2020, 49, 191-202. [CrossRef] [PubMed]

26. Cunha, E.J.; Guterres, A.P.M.; Godoy, B.S.; Juen, L. Wing dimorphism in semiaquatic bugs (Hemiptera, Heteroptera, Gerromorpha) as a tool for monitoring streams altered by oil palm plantation in the Amazon. Ecol. Indic. 2020, 117, 106707. [CrossRef]

27. Rosenberg, D.M.; Resh, V.H. Freshwater Biomonitoring and Benthic Macroinvertebrates; Chapman \& Hall: New York, NY, USA, 1993; p. 487.

28. Guterres, A.P.M.; Cunha, E.J.; Juen, L. Tolerant semiaquatic bugs species (Heteroptera: Gerromorpha) are associated to pasture and conventional logging in the Eastern Amazon. J. Insect Conserv. 2021, 25, 1-13. [CrossRef]

29. Giehl, N.F.S.; Brasil, L.S.; Dias-Silva, K.; Nogueira, D.S.; Cabette, H.S.R. Environmental Thresholds of Nepomorpha in Cerrado Streams, Brazilian Savannah. Neotropic. Entomol. 2019, 48, 186-196. [CrossRef]

30. Strahler, A.N. Quantitative analysis of watershed geomorphology. EOS Trans. Am. Geophys. Union 1957, 38, 913-920. [CrossRef]

31. Diniz, T.D.A. Caracterização Climática da Amazônia Oriental. Pesquisa Sobre Utilização e Conservação de Solo na Amazônia Oriental; Embrapa Cpatu: Belém, Portugal, 1986; p. 291.

32. Peel, M.C.; Finlayson, B.L.; Mcmahon, T.A. Uptade world map of the Köppen-Geiger climate classification. Hydrol. Earth Syst. Sci. 2007, 11, 1633-1644. [CrossRef]

33. Gardner, T.A.; Ferreira, J.; Barlow, J.; Lees, A.C.; Parry, L.; Zuanon, J. A social and ecological assessment of tropical land uses at multiple scales: The Sustainable Amazon Network. Philos. Trans. R. Soc. 2013, 368, 1-11. [CrossRef]

34. Oliveira-Junior, J.M.B.; Teodósio, M.A.; Juen, L. Patterns of co-occurrence and body size in dragonflies and damselflies (Insecta: Odonata) in preserved and altered Amazonian streams. Austral. Entomol. 2021, 60, 436-450. [CrossRef]

35. Baptista, D.F.; Dorvillé, L.F.M.; Buss, D.F.; Nessimian, J.L. Spatial and temporal organization of aquatic insects assemblages in the longitudinal gradient of a tropical river. Rev. Bras. Biol. 2001, 61, 295-394. [CrossRef]

36. Heino, J. Taxonomic surrogacy; numerical resolution and responses of stream macroinvertebrate communities to ecological gradients: Are the inferences transferable among regions? Ecol. Indic. 2014, 36, 186-194. [CrossRef]

37. Brasil, L.S.; Oliveira-Junior, J.M.B.; Calvão, L.B.; Carvalho, F.G.; Monteiro-Júnior, C.S.; Dias-Silva, K.; Juen, L. Spatial, biogeographic and environmental predictors of diversity in Amazonian Zygoptera. Insect Conserv. Divers. 2018, 11, 174-184. [CrossRef]

38. Kaufmann, P.R.; Levine, P.; Robison, E.G.; Seeliger, C.; Peck, D.V. Quantifying Physical Habitat in Wadeable Streams; United States Environmental Protection Agency: Washington, DC, USA, 1999. 
39. Peck, D.V.; Herlihy, A.T.; Hill, B.H.; Hughes, R.M.; Kaufmann, P.R.; Klemm, J.; Lazorchak, J.M.; Mccormick, F.H.; Peterson, S.A.; Ringold, P.L.; et al. Environmental Monitoring and Assessment Program-Surface Waters Western Pilot Study: Field Operations Manual for Wadeable Streams; Environmental Protection Agency, Office of Research and Development: Washington, DC, USA, 2006.

40. Cabette, H.R.S.; Giehl, N.F.D.S.; Dias-Silva, K.; Juen, L.; Bastista, J.D. Distribuição de Nepomorpha e Gerromorpha (Insecta: Heteroptera) da Bacia do Rio Suiá-Miçú, MT: Riqueza relacionada à qualidade de água e de habitat. In Gestão e Educação Ambiental: Água, Biodiversidade e Cultura; Santos, J.E., Galbiati, C., Moschini, L.E., Eds.; RiMa: São Carlos, Brazil, 2010 ; pp. $113-137$.

41. Kenaga, E.E. The genus Telmatometra Bergroth (Hemiptera-Gerridae). Univ. Kans. 1941, 17, 169-183.

42. Kenaga, E.E. A new genus in the Holobatinae (Gerridae-Hemiptera). J. Kans. Entomol. Soc. 1942, 15, $136-141$.

43. Drake, C.J.; Hussey, R.F. Concerning some American Microvelia (Hemiptera: Veliidae). Fla. Entomol. 1951, 34, 137-145. [CrossRef]

44. Nieser, N.; Melo, A.L. Os Heterópteros Aquáticos de Minas Gerais: Guia Introdutório com Chave de Identificação para as Espécies de Nepomorpha e Gerromorpha; Universidade Federal de Minas Gerais: Belo Horizonte, Brazil, 1997.

45. Moreira, F.F.F.; Alecrim, V.; Ribeiro, J.R.I.; Nessimian, J.L. Identification key to the Gerridae (Insecta: Heteroptera: Gerromorpha) from the Amazon River floodplain, Brazil, with new records for the Brazilian Amazon. Zoologia 2011, 28, 269-279. [CrossRef]

46. Moreira, F.F.F.; Barbosa, J.F. A new Rhagovelia (Hemiptera: Heteroptera: Veliidae) from the Brazilian Amazon, with a key to species of the robusta group known from the country. Zootaxa 2014, 3790, 595-600. [CrossRef]

47. Aristizábal-García, H.; Floriano, C.F.B.; Moreira, F.F.F.; Bispo, P.C. New species and notes on Microveliinae from northern South America (Hemiptera: Heteroptera: Veliidae). Zootaxa 2015, 3980, 591-596. [CrossRef]

48. Magalhães, O.M.; Moreira, F.F.F.; Galvão, C.A. New species of Rhagovelia Mayr, 1865 (Hemiptera: Heteroptera: Veliidae) from Pará state, with an updated key to Brazilian species of the robusta group. Zootaxa 2016, 4171, 586-594. [CrossRef]

49. Floriano, C.F.B.; Paladini, A.; Cavichioli, R.R. Systematics of the South American species of Cylindrostethus Mayr, 1865 (Hemiptera: Heteroptera: Gerridae), with a new species from Amazonian Brazil and Peru. Invertebr. Syst. 2016, 30, 431-462. [CrossRef]

50. Dray, S.; Bauman, D.; Blanchet, G.; Borcard, D.; Clappe, S.; Guenard, G.; Wagner, H.H. Package 'adespatial'. R Package 2018, 2018, 3-8. Available online: http://cran.nexr.com/web/packages/adespatial/adespatial.pdf (accessed on 20 April 2020).

51. Oksanen, J.; Blanchet, F.G.; Kindt, R.; Legendre, P.; O’Hara, R.B.; Simpson, G.L.; Wagner, H. R Package; Version 1.17-4; Vegan: Community Ecology Package; CRAM. 2010. Available online: http:/ /CRAN.R-project.org/package=vegan (accessed on 20 April 2020).

52. Zar, J.H. Biostatistical Analysis; Pearson Prentice-Hall: Upper Saddle River, NJ, USA, 2010.

53. R Core Team. R: A Language and Environment for Statistical Computing; R Foundation for Statistical Computing: Vienna, Austria, 2019; Available online: https:/ / www.R-project.org/ (accessed on 20 April 2020).

54. Shimano, Y.; Juen, L.; Salles, F.F.; Nogueira, D.S.; Cabette, H.S.R. Environmental and spatial processes determining Ephemeroptera (Insecta) structures in tropical streams. Ann. Limnol. Int. J. Lim. 2013, 49, 31-41. [CrossRef]

55. Oliveira-Junior, J.M.B.; Juen, L. Structuring of Dragonfly Communities (Insecta: Odonata) in Eastern Amazon: Effects of Environmental and Spatial Factors in Preserved and Altered Streams. Insects 2019, 10, 322. [CrossRef]

56. Poff, N.L.; DeCino, R.D.; Ward, J.V. Size-dependent drift responses of mayflies to experimental hydrologic variation: Active predator avoidance of passive hydrodynamic displacement? Oecologia 1991, 88, 577-586. [CrossRef] [PubMed]

57. Hawkins, B.A.; Diniz-Filho, J.A.F.; Jaramillo, C.A.; Soeller, S.A. Climate, niche conservatism, and the global bird diversity gradient. Am. Nat. 2007, 170, 16-27. [CrossRef] [PubMed]

58. Chase, J.M. Community assembly: When should history matter? Oecologia 2003, 136, 489-498. [CrossRef] [PubMed]

59. Borcard, D.; Gillet, F.; Legendre, P. Numerical Ecology with R; Springer: New York, NY, USA, 2011; p. 302.

60. Pereira, D.F.G.; De Oliveira, J.M.B.; Juen, L. Environmental changes promote larger species of Odonata (Insecta) in Amazonian streams. Ecol. Indic. 2018, 98, 179-192. [CrossRef]

61. Mendes, T.P.; Oliveira-Junior, J.M.B.; Cabette, H.S.R.; Batista, J.D.; Juen, L. Congruence and the Biomonitoring of Aquatic Ecosystems: Are Odonate Larvae or Adults the Most Effective for the Evaluation of Impacts. Neotrop. Entomol. 2017, 46, 631-641. [CrossRef]

62. Oliveira-Junior, J.M.B.; Dias-Silva, K.; Teodósio, M.A.; Juen, L. The response of neotropical Dragonflies (Insecta: Odonata) to local and regional abiotic factors in small streams of the Amazon. Insects 2019, 10, 446. [CrossRef]

63. Luiza-Andrade, A.; Brasil, L.S.; Benone, N.L.; Shimano, Y.; Farias, A.P.J.; Montag, L.F.; Dolédec, S.; Juen, L. Influence of oil palm monoculture on the taxonomic and functional composition of aquatic insect communities in eastern Brazilian Amazonia. Ecol. Indic. 2017, 82, 478-483. [CrossRef]

64. Savage, A. The distribution of Corixidae in relation to water quality of British lakes: A monitoring model. Freshw. Forum 2010, 4, 32-61.

65. Couceiro, S.R.M.; Hamada, N.; Luz, S.L.B.; Forsberg, B.R.; Pimentel, T.P. Deforestation and sewage effects on aquatic macroinvertebrates in urban streams in Manaus, Amazonas, Brazil. Hydrobiologia 2007, 575, 271-284. [CrossRef]

66. Karaouzas, L.; Gritzalis, K.C. Local and regional factors determining aquatic and semi-aquatic bug (Heteroptera) assemblages in rivers and streams of Greece. Hydrobiologia 2006, 573, 199-212. [CrossRef]

67. Taybi, A.F.; Mabrouki, Y.; Bozdoğan, H.; Millan, A. Are aquatic Hemiptera good indicators of environmental river conditions? Aquat. Ecol. 2021, 55, 791-806. [CrossRef] 
68. Godoy, B.S.; Queiroz, L.L.; Lodi, S.; Oliveira, L.G. Environment and spatial influences on aquatic insect communities in cerrado streams: The relative importance of conductivity, altitude, and conservation areas. Neotrop. Entomol. 2017, 46, 151-158. [CrossRef] [PubMed]

69. Leal, C.G.; Pompeu, P.S.; Gardner, T.A.; Leitão, R.P.; Hughes, R.M.; Kaufmann, P.R.; Zuanon, J.; De Paula, F.R.; Ferraz, S.F.B.; Thomson, J.R.; et al. Multi-scale assessment of human-induced changes to Amazonian instream habitats. Landsc. Ecol. 2016, 31, 1725-1745. [CrossRef]

70. Hu, D.L.; Chan, B.; Bush, J.W.M. The hydrodynamics of water strider locomotion. Nature 2003, 424, 663-666. [CrossRef] 